\title{
EFFECT OF GOOD AND POOR POSTHARVEST HANDLING PRACTICES ON THE LOSSES IN LETTUCE AND TOMATO SUPPLY CHAINS
}

\author{
İbrahim Sani Özdemir*, Hatice Semizer Aksoy \\ TÜBİTAK Marmara Research Centre, Food Institute, Gebze, Kocaeli, Turkey
}

Geliş / Received: 12.03.2021; Kabul / Accepted: 18.05.2021; Online bask1 / Published online: 24.05.2021

Ozdemir, I.S., Semizer Aksoy, H. (2021). Effect of good and poor postharvest handling practices on the losses in lettuce and tomato supply chains. GIDA (2021) 46 (4) 859-871 doi: 10.15237/gida.GD21049

Özdemir, İ.S., Semizer Aksoy, H. (2021). İyi ve yanlış hasat sonrası uygulamaların marul ve domates tedarik zincirlerinde yaşanan kayıplar üzerine etkisi. GIDA (2021) 46 (4) 859-871 doi: 10.15237 /gida.GD21049

\begin{abstract}
The amount of losses caused by good (GHP) and poor (PHP) practices in the post-harvest processes of lettuce and tomato was determined under real supply chain conditions. Along with the commercial losses, changes in the nutritional and microbiological quality of crops were also quantified. The results showed that the weight loss of lettuce and tomato was reduced three and nine-fold, respectively by GHP during supply chains. The retail-display and transportation of the product in the postharvest process were determined to be the most critical supply chain stages affecting quality. The nutritional quality of crops exposed to PHP has shown differences by both crop and compound. The microbial quality of the produces, however, was adversely affected by the poor postharvest handling practices. In conclusion, still huge amounts of postharvest losses can be avoided if already known good postharvest handling practices are employed with a holistic perspective in produce supply chains.
\end{abstract}

Keywords: Food waste, postharvest, cold chain, lettuce, tomato

\section{IYII VE YANLIŞ HASAT SONRASI UYGULAMALARIN MARUL VE DOMATES TEDARİK ZİNCİRLERİNDE YAŞANAN KAYIPLAR ÜZERİNE ETKİSİ}

\section{Öz}

Marul ve domateste hasat sonrası süreçlerdeki iyi ve yanlış uygulamalar, sonucu oluşan kayıpların miktarı reel tedarik zinciri koşullarında belirlenmiştir. Çalışmada ticari kayıpların yanı sıra, ürünlerin besin içerikleri ve mikrobiyolojik kalitesindeki değişimler de ölçülmüştür. Sonuçlar, marul ve domateste hasat sonrası süreçlerdeki iyi uygulamaların ağırlık kaybında, sırasıyla, üç ve dokuz kat azalmayla sonuçlandığını göstermiştir. Hasat sonrası süreçte, ürünün perakende-teşhiri ve nakliyesinin, kaliteyi etkileyen en kritik tedarik zinciri aşamaları olduğu belirlenmiştir. Hasat sonrası süreçte yapılan yanlış uygulamaların ürünlerin besin kalitesi üzerine etkisi ise ürüne ve bileşiğe bağlı olarak farklılıklar göstermiştir. Buna karşın, hasat sonrasındaki yanlış uygulamaların ürünlerin mikrobiyal kalitesini olumsuz etkilediği de belirlenmiştir. Sonuç olarak, hâlihazırda bilinen hasat sonrası süreçlerdeki iyi uygulamaların, ürün tedarik zincirlerinde bütünsel bir bakış açısıyla kullanılması durumunda hasat sonrası kayıpların büyük ölçüde engellenebileceği belirlenmiştir.

Anahtar kelimeler: Gıda kayıpları, hasat sonrası, soğuk zincir, marul, domates

* Corresponding author / Yazışmalardan sorumlu yazar:

$\triangle$ : ibrahim.ozdemir@tubitak.gov.tr

(c: (+90) 2626773275

與: (+90) 2626412309

İbrahim Sani Özdemir ORCID ID: 0000-0002-6159-0847

Hatice Semizer Aksoy ORCID ID: 0000-0003-4191-6042 


\section{INTRODUCTION}

With the ever-growing world population and the consequent risk of food shortage in coming years, reducing postharvest food losses became a serious concern more than ever.

Fresh fruits and vegetables are perishable products that can rapidly lose their quality after harvest. The rate and extent of the quality loss are directly related to extrinsic factors such as temperature, relative humidity, and surrounding atmospheric composition (Kader, 2005). Among these factors, the temperature has the most noticeable impact in keeping the quality of fresh produces since a $10^{\circ} \mathrm{C}$ of increase in temperature can double the rate of majority of the deteriorative reactions, growth of spoilage bacteria, and nutrient loss (Saltveit, 2003). Therefore, keeping the temperature as low as possible throughout the supply chain is the basic strategy applied for reducing postharvest produce losses. Besides, many fruits and vegetables are highly susceptible to transpiration which can result in shriveling or wilting which negatively affects the consumer appeal. Thus, during postharvest handling of fresh produces the relative humidity of the surrounding atmosphere should be kept high either by using appropriate packaging materials or humidification systems during storage, transport, and retail display (Paull, 1999). However, temperature and relative humidity control systems bring extra costs which limit their adoption by fresh produce supply chain actors (Hodges et al., 2011).

There exist several reports aimed at quantifying postharvest losses in fruit and vegetable supply chains. In the majority of these studies, the amount of losses were quantified by estimation using consumption and production data (Lebersorger and Schneider, 2014; Marsh et al., 2001; Mena et al., 2014). Although they provide valuable information about the overall amount of food losses, such studies suffer from the fact that the timing of production and consumption of a unit of food product does not always occur within the same period for which data is reported (Marsh et al., 2001). In some other studies, the amount of fresh produce losses were quantified in simulated supply chain conditions in terms of temperature and relative humidity (Kelly et al., 2019; Nunes et al., 2011, 2009). However, in real supply chain conditions, factors other than temperature and relative humidity, such as mechanical injuries, microbial contamination, can also negatively affect the quality of the fresh produces which can cause an increase in product losses. Only in a few studies, the postharvest losses were quantified in real supply chain conditions in which the main objective was to quantify the postharvest losses for a specific commodity and country (Gogo et al., 2017; Managa et al., 2018; Rediers et al., 2009). However, to the best of our knowledge, no study has been carried out yet which aimed at comparing the postharvest losses in supply chains with good and poor handling practices. Such studies would be of interest, because, since the results will be obtained from real life conditions, it would be more convincing for different actors of the fresh produce supply chain who are reluctant to invest in necessary infrastructure for better preserving the quality of fresh produces.

The aim of this study, therefore, was to quantify the benefit of applying good handling practices in reducing post-harvest losses, both commercial and nutritional, in real supply chain conditions in comparison with the poor handling practices. The study was carried out on lettuce (Lactuca sativa cv. Lollo rosso) and tomato (Solanum bycopersicum cv. Kinali) supply chains which are among the leading fresh produces in terms of production volume.

\section{MATERIALS AND METHODS \\ Plant material}

Both lettuces (Lactuca sativa cv. lollo rosso) and tomatoes (Solanum bycopersicum cv. Kinali) were procured from producers located at Antalya province which is one of the major agricultural regions of Turkey. Lettuces was supplied from the glass house of Erüst Tarımcillk A.Ş. and tomatoes from Enerji Tarım A.Ş. The final destination of the produces was Istanbul which is the most agglomerated city of Turkey with 15 million habitants (Turkstat, 2018) and $698 \mathrm{~km}$ far from Antalya. 

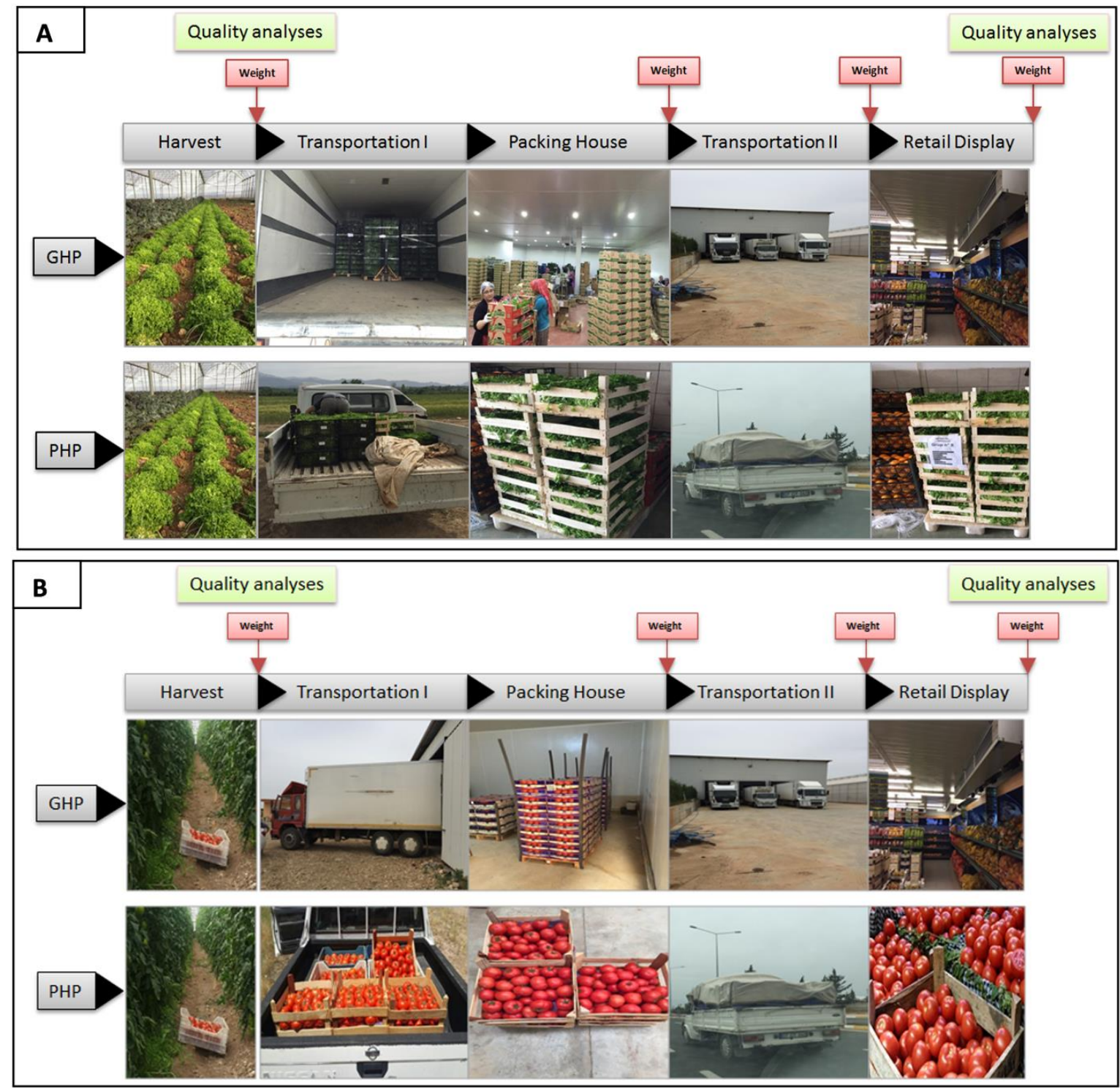

Figure 1 The schematic representation of the structure of A) lettuce and B) tomato supply chains and sampling stages (GHP: good handling practices and PHP: poor handling practices).

\section{Experimental approach}

In order to compare the amount of produce loses between GHP and PHP supply chains, firstly, the good and poor postharvest practices were determined for each supply chain stages of lettuce and tomatoes, namely, harvest, transportation, packaging and retail-display. These practices are determined on the basis of the observations of our suppliers and general literature in the field. Regarding the harvest stage, the utilization of over-mature produces and wooden boxes was considered as the poor practice. For lettuces, when the overmature heads are forced to fit in the standard wooden boxes to meet the standard number of items expected in a box, they get squeezed and leads to the fracture of the midribs of the leaves. In case of tomatoes, over mature fruits, which are softer, get easily injured during supply chain and accelerates the ripening of the whole batch due to stress-induced ethylene emission. In addition, scratchy surface of the wooden boxes also results in additional injuries. 
Therefore, with respect to good handling practices produces should only be harvested at optimum maturity and over mature produces should be avoided. Regarding the packaging stage, lack of packaging for limiting transpiration is considered as poor handlings practice for lettuce and tomatoes whereas good handling practice dictates the utilisation of such packaging. For the transportation and retail-display stages, maintaining cool-chain is considered as good handling practice and its absence as poor handling practice. It should be noted that different handling practices also exists for each supply chain stage such as the utilisation of nebulized water spray during retail-display especially when the refrigeration cannot be afforded. However, since in this study it was aimed at comparing the best and worst supply chain scenarios, substitutive applications which are used in the absence of the best practice were omitted.

As can be seen from (Figure 1A-B), two batches of lettuces (or tomatoes), each consisting of 10 boxes, harvested from the same glasshouse were prepared and supplied to the market by applying good and poor handling practices at different stages of the supply chain.

The first batch, comprising lettuces at optimum maturity for marketing, was used for the GHP supply chain study. The second batch comprising overmature lettuces was used for the PHP supply chain study. Plastic and wooden boxes were used for GHP and PHP batches, respectively, and temperature loggers (Trix-8, LogTag, New Zeland), which recorded the temperature at $5 \mathrm{~min}$ intervals were placed in one of the boxes of each batch. Before transportation, each batch was weighed (10 boxes together) and samples were taken for the biochemical and microbiological analysis. GHP batch was then transported to the distribution house with a refrigerated truck whereas the PHP batch was transported without refrigeration. It took approximately $30 \mathrm{~min}$ to arrive the distribution house. Upon arrival at the distribution house, each lettuce head in the GHP batch was packed with a macro perforated packing film to reduce transpiration. The temperature of the packaging and storage rooms was at $15^{\circ} \mathrm{C}$. For the PHP batch, secondary packing was not done and they were stored at ambient temperature until loading for transportation. The weight of lettuce batches were recorded (weight of secondary packages were subtracted) before transportation to their final destination. GHP batch was transported with a refrigerated trailer in which the temperature was set at $14^{\circ} \mathrm{C}$. PHP batch was transported without refrigeration. When upon arrival to the point of sell in Istanbul after a drive of approximately $10 \mathrm{~h}$, lettuce batches were weighed. Then GHP batch was placed at a refrigerated display area of $4^{\circ} \mathrm{C}$ whereas the PHP batch was displayed at ambient conditions for 2 days. At the end of two days of display period batches were weighed and each lettuce was evaluated for its saleability. Samples from each batch were also taken for the biochemical and microbiological analysis.

For the tomato supply chain study same experimental procedure was followed with the difference that the inside temperature of the trailer for long-distance transportation and display area of the tomatoes were set at $12^{\circ} \mathrm{C}$.

\section{Biochemical analysis Sample preparation}

For the biochemical and microbiological analyses of lettuce, 3 heads of lettuces were selected randomly from the 10 boxes constituting the batch. The leaves of each lettuce head were detached from the main rib and, starting from the youngest leaf, every 3 successive leaves were grouped to represent leaves of different maturity. Then, from each group of 3 leaves 1 leaf was randomly selected. These selected leaves were pooled to represent the lettuce head. By this was three samples from the same lettuce head comprising similar amount of leaves of different maturity could be established. One of these samples was used for lutein, $\beta$-carotene and riboflavin analysis and other two samples were used for sugar/organic acid and microbiological analysis. In this way, it was aimed at minimizing the effect of leaf maturity on the biochemical and microbial analysis. 
For the tomatoes, 27 tomatoes were randomly selected in total from each batch of 10 boxes. Then selected tomatoes were divided into 3 groups comprising 9 fruits. One of these groups were used for lycopene and $\beta$-carotene analysis, another for sugar/organic acid analysis and the remaining one for the microbiological analysis. Prior to each analysis homogenates were prepared by using 3 fruits each time which enabled triplicate measurements. All the edible parts of the tomato including the peel and seeds were used for the analysis.

\section{$\beta$-carotene, lutein and lycopene analysis}

A five $g$ of sample homogenate was mixed with the extraction solution of $50 \mathrm{~mL}$ Methanol/THF $(1: 1, \mathrm{v} / \mathrm{v})$ containing $0.1 \%(\mathrm{~m} / \mathrm{v})$ pyrogallol and filtered under suction. Then extracts were saponified with $12.5 \mathrm{~mL}$ of $50 \% \mathrm{KOH}$ solution at room temperature for $2 \mathrm{~h}$. The extract was further mixed with $50 \mathrm{~mL}$ petroleum ether and the filtrate was washed 2 times with $50 \mathrm{~mL} \mathrm{10 \%}$ $\mathrm{NaCl}$. After solvent evaporation, the remaining residue was dissolved in methanol/THF (1:1, $\mathrm{v} / \mathrm{v}$ ) solution and the total volume was brought to $25 \mathrm{~mL}$. Prior to HPLC analysis, the extract was filtered through a $\quad 0.45 \quad \mu \mathrm{m}$ polytetrafluoroethylene filter (Lubitech, Songjiang, China).

A twenty $\mu$ l of sample was injected into the HPLC system (Shimadzu 20 Series, LC Solutions, Japan). The separation of $\beta$-carotene, lutein, and lycopene was performed on a reverse-phase Zorbax ${ }^{\circledR}$ ODS column (ID: $4.6 \mathrm{~mm}$; particle size: $5 \mu \mathrm{m}$ ). The flow rate of the mobile phase (95\% methanol: $5 \%$ THF) was $0.8 \mathrm{~mL} / \mathrm{min}$. Carotenoids were detected with an UV-detector at $470 \mathrm{~nm}$. The results were the mean of three replicates which were expressed as $\mu \mathrm{g} / 100 \mathrm{~g}$ FW.

\section{Sugars and organic acids}

A five $g$ of sample homogenate was mixed with $20 \mathrm{~mL}$ of ultra-pure water at $4^{\circ} \mathrm{C}$ and centrifuged at $25155 \mathrm{~g}$ for $20 \mathrm{~min}$ at $4^{\circ} \mathrm{C}$. The supernatant was filtered through a $0.45 \mu \mathrm{m}$ filter (Lubitech, Songjiang, China) and injected into the HPLC system (LC-20AD Prominence, Shimadzu Corp., Kyoto, Japan) equipped with a Rezex RCM column $(300 \times 7.8 \mathrm{~mm}$; Phenomenex, Torrance, $\mathrm{CA})$ at $80^{\circ} \mathrm{C}$. The mobile phase was ultra-pure water which was eluted isocratically at a flow rate of $0.6 \mathrm{~mL} / \mathrm{min}$. Sugars were detected with a refractive index detector (RID-10A) and the results were expressed as $\mathrm{g} / 100 \mathrm{~g}$ FW.

The same filtrate was used for the HPLC analysis of organic acids. Separations were carried out on a Rezex ROA column $(300 \times 7.8 \mathrm{~mm}$; Phenomenex, Torrance, CA) thermostated at $55^{\circ} \mathrm{C}$. The mobile phase was $0.005 \mathrm{~N} \mathrm{H}_{2} \mathrm{SO}_{4}$ with a flow rate of $0.5 \mathrm{~mL} / \mathrm{min}$. Organic acids were detected with a diode array detector at $210 \mathrm{~nm}$ and $245 \mathrm{~nm}$, respectively. Organic acids were expressed as $\mathrm{g} / 100 \mathrm{~g}$ FW except for ascorbic acid which was expressed as $\mathrm{mg} / 100 \mathrm{~g}$ FW.

\section{Riboflavin analysis}

A five $g$ of the lettuce homogenate was mixed with $60 \mathrm{~mL}$ of $0.1 \mathrm{M} \mathrm{HCl}$. The mixture was then heated in a retort at $120^{\circ} \mathrm{C}$ for $30 \mathrm{~min}$. After cooling down to room temperature, the $\mathrm{pH}$ of the mixture was adjusted to 4.5 with $2 \mathrm{M}$ sodium acetate. Then $250 \mathrm{mg}$ clara-diastase, $50 \mathrm{mg}$ papain, $20 \mathrm{mg}$ alfa-amylase, $0.5 \mathrm{~mL}$ acid phosphatase, and $1 \mathrm{~mL} \mathrm{~B}$-glucosidase enzymes were added. The mixture was let for $3 \mathrm{~h}$ in a water bath at $45^{\circ} \mathrm{C}$ with continuous shaking. After cooling to room temperature, the volume of the mixture was brought to $100 \mathrm{~mL}$ with $0.1 \mathrm{~N} \mathrm{HCl}$ and centrifuged at $4500 \mathrm{rpm}$ for $5 \mathrm{~min}$ at $20^{\circ} \mathrm{C}$. The supernatant was filtered through a $0.45 \mu \mathrm{m}$ filter (Lubitech, Songjiang, China) and $20 \mu \mathrm{l}$ of extract was injected into the HPLC (Shimadzu 20 Series, Shimadzu corp., Japan). The riboflavin was separated using an Eclipse XCD-C18 column (pore size $5 \mu \mathrm{m}, 4.6 \times 150 \mathrm{~mm}$; Agilent), isocratically at ambient temperature with water:methanol $(4: 1, \mathrm{v} / \mathrm{v})$ at $1 \mathrm{~mL} / \mathrm{min}$, also detected with a fluorescence detector. Excitation and emission wavelengths for riboflavin were 445 and $545 \mathrm{~nm}$, respectively. The results were the mean of three replicates which were expressed as $\mu \mathrm{g} / 100 \mathrm{~g}$ FW.

\section{Microbial analysis}

Samples of $25 \mathrm{~g}$ were homogenized in $225 \mathrm{~mL}$ of sterile peptone water solution $(0.1 \%)$ in a sterile 
stomacher bag with a Stomacher (Tekmar, Cincinnati, $\mathrm{OH}$ ) for approximately $1 \mathrm{~min}$. Tenfold dilution series were made in peptone water solution. A $0.1 \mathrm{~mL}$ sample of each filtrate or its appropriate dilution was spread on agar plates. The culture media and conditions used for the enumeration of the selected microorganisms were as follows: (1) Dichloran Rose Bengal Chloramphenicol (DRBC) Agar (Merck) containing $100 \mu \mathrm{g} / \mathrm{mL} \quad$ chloramphenicol incubated at $25{ }^{\circ} \mathrm{C}$ for 5 days for yeast and moulds; (2) Pseudomonas Agar Base (Oxoid) incubated at $30{ }^{\circ} \mathrm{C}$ for $36 \mathrm{~h}$ for Pseudomonas spp.; (3) Violet Red Bile Lactose (VBRL) Agar (Oxoid) for coliform bacteria at $37^{\circ} \mathrm{C}$ for $24 \mathrm{~h}$. Microbial colonies were reported as $\log \mathrm{cfu} / \mathrm{g}$ of tissue.

\section{Saleability ratio}

In order to determine the saleability ratio of lettuces, all the lettuce heads in a batch of ten boxes were visually inspected for fresh appearance and absence of defects by 3 assessors, which have prior experience in retailing and fresh produce quality. Then the assessors were asked to trim the outer leaves until reaching the leaves with acceptable visual appearance. The ratio of the difference between the weight measurements taken before and after trimming to the initial weight of the lettuce head was used as a percent saleability ratio. The saleability ratio of tomatoes was determined by the same assessors who evaluated each tomato for the absence of defects (mold growth, bruises, wilting etc.) which makes tomatoes inapt for marketing. The number of the tomatoes without defects in a batch was expressed in percentage was used as the saleability ratio for the tomatoes.

\section{Statistical analysis}

Unless otherwise indicated all the analyses were studied at least in triplicate. The analysis of variance (ANOVA) was used to test the significance $(P<0.05)$ of the mean differences. In order to figure out the significantly different means Tukey's HSD (Honest Significant Difference) test was used. XLStat software, version 2010.2.02 (Addinsoft, Paris, France) was used for the statistical analysis.

\section{RESULTS AND DISCUSSION}

\section{Lettuce supply chain}

Weight loss and saleability

The time-temperature histories of the GHP and PHP supply chains were given in Figure 2. The averages of the temperatures recorded all through the supply chains were $7.5^{\circ} \mathrm{C}$ and $20.0^{\circ} \mathrm{C}$, respectively.

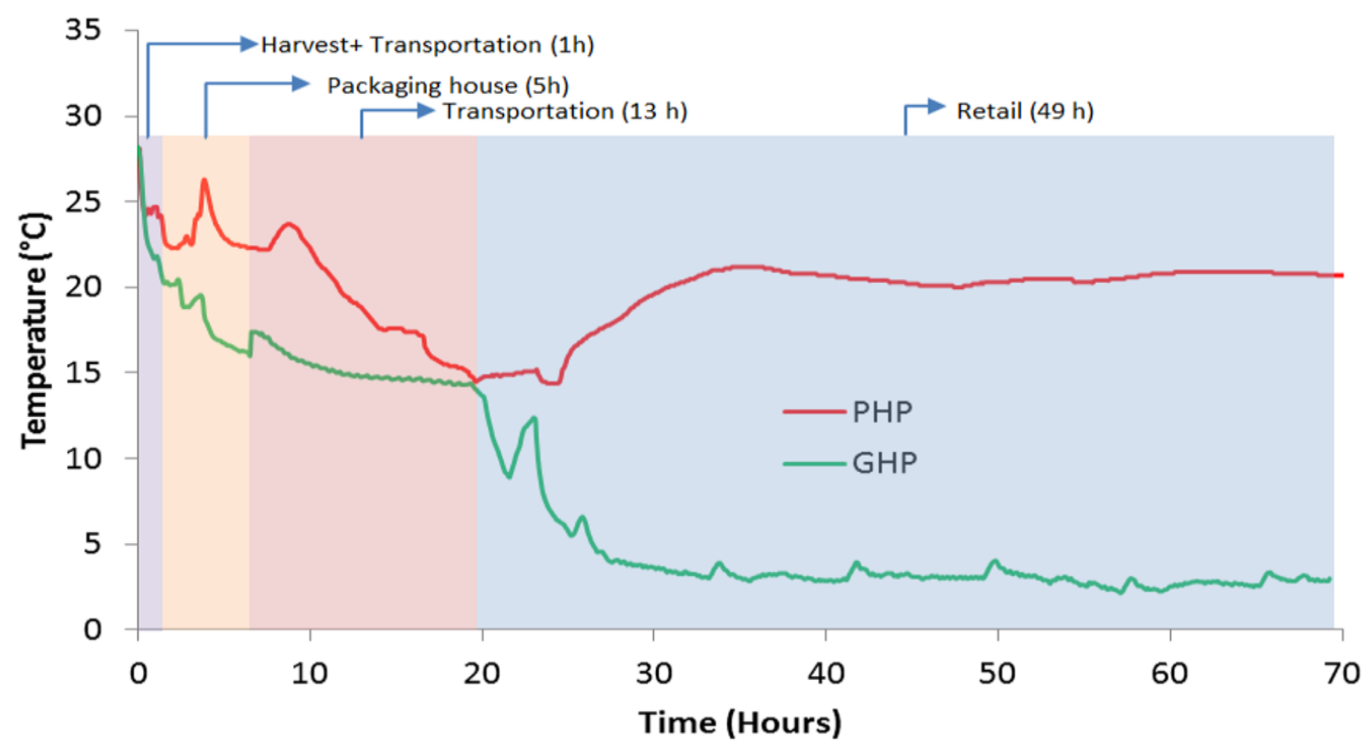

Figure 2 The time-temperature histories of the lettuce supply chain with good (GHP) and poor postharvest handling practices (PHP). 
The fresh and turgid appearance of lettuce is the most important criteria which affect the purchasing decision of the consumers and it is strongly linked to the water content of the lettuce (Agüero et al., 2011). The fresh weight loss of leafy vegetables mainly results from respiration and transpiration. During respiration water and carbon dioxide are released as a result of oxidation of carbohydrates, resulting in dry matter loss. However, in leafy vegetables, the weight loss due to respiration is negligible compared to the amount lost due to transpiration if they are stored for periods shorter than 7 days (Wiley, 1994).
Therefore, in the present study, the weight loss of lettuce heads was assumed to occur mainly due to transpiration. The lettuces from the PHP supply chain lost $20 \%$ of their initial weight at the end of the trial whereas lettuces from the GHP supply chain lost only $6.6 \%$ (Table 1). The highest amount of weight loss occurred at retail display and long distance transportation stages which are in line with the findings of Managa et al. (2018) who also reported that the amount of weight loss in crisphead lettuces was the highest at the retail display stage of the supply chain.

Table 1 The duration and weight loss data for each step of lettuce and tomato supply chains (PHP: poor handling practices, GHP: good handling practices). Saleability percentage of lettuces and tomatoes were determined at the end of the retail display period.

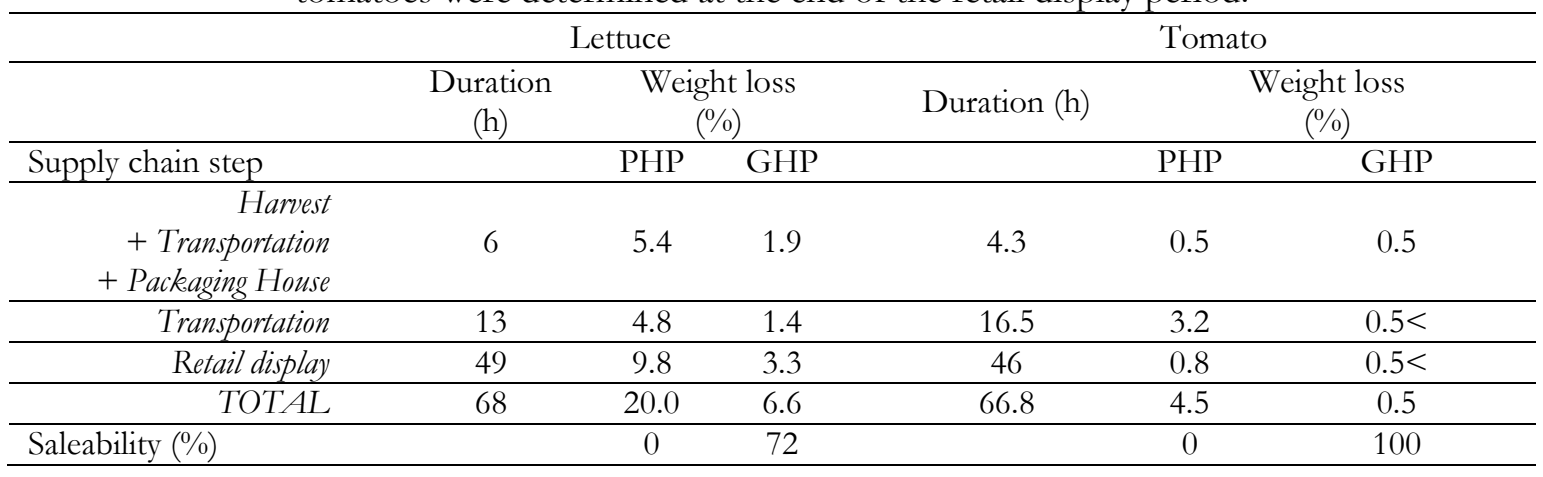

In general, the price of fruit and vegetables is determined on a weight basis. In this respect, the amount of weight loss corresponds directly to commercial loss. However, the repercussion of the weight loss on the visual appearance, thus, consumer perception is also vital for the determination of the commercial loss. It was reported that consumers do not purchase lettuces which lost more than $3 \%$ of water due to their unacceptable wilted appearance (Paull, 1999). As seen from Table 1, in this study the lettuce heads from the PHP supply chain which lost $20 \%$ weight were totally unacceptable whereas $72 \%$ of the lettuce heads from the GHP supply chain were still saleable which lost only $6.6 \%$. When compared to the threshold value (3\% weight loss) reported by Paull (1999) our results for the GHP supply chain can be considered as contradictory. However, in the study of Paull (1999) authors did not quantify the remaining acceptable portion of the lettuces after trimming the wilted leaves as it was done in this study. Therefore, our results indicate that setting a weight loss threshold value for the visual acceptance of outer leaves of lettuces does not reflect the real amount of lettuce lost due to consumer rejection.

\section{Changes in microbial quality}

The changes in the microbiological quality of the lettuces were evaluated on the basis of coliform and Pseudomonas counts. Coliforms are generally accepted as indicator bacteria for the hygiene level of the fresh produces (Falomir et al., 2010). The Pseudomonas spp. are the most prevalent bacteria which are associated with the spoilage of the lettuces (Geysen et al., 2006). After two days of retail display, the coliform counts were significantly $(P<0.05)$ higher in lettuces subjected to PHP than GHP whereas no significant difference was observed for Pseudomonas counts (Table 2). The possibility of contamination due to lack of proper packaging and the high 
temperatures from the PHP supply chain might have led to higher coliform counts in PHP supply chain samples than those from the GHP supply chain in lettuces.

Table 2 Microbial load of lettuces at harvest and at the end of retail display which were supplied through poor ( $\mathrm{PHP}$ ) and good handling practices (GHP).

\begin{tabular}{lccc}
\hline & At harvest & \multicolumn{2}{c}{ After 2 days at retail display } \\
\hline & & PHP & GHP \\
Coliform $(\operatorname{logCFU} / \mathrm{g})$ & $4.43 \pm 0.62 \mathrm{a}$ & $5.88 \pm 0.60 \mathrm{~b}$ & $4.92 \pm 0.73 \mathrm{a}$ \\
Pseudomonas $(\log \mathrm{CFU} / \mathrm{g})$ & $3.80 \pm 1.04 \mathrm{a}$ & $5.79 \pm 0.40 \mathrm{~b}$ & $5.18 \pm 0.75 \mathrm{~b}$ \\
\hline
\end{tabular}

\section{Changes in nutritional quality}

In lettuce, ascorbic acid, $\beta$-carotene, lutein, and riboflavin are known as the major phytochemicals of nutritional value (Kim et al., 2016). As a potent anti-oxidant ascorbic acid content of fruits and vegetables is known to decrease when produces are exposed to stress conditions such as high temperatures during storage and processing. Therefore, ascorbic acid is generally accepted as an indicator compound for the nutritive value of fruits and vegetables (Agüero et al., 2011). The ascorbic acid content of lettuces decreased during the course of the supply chain and the extent of decrease was slightly higher, but not significant $(P>0.05)$, in lettuces subjected to PHP than GHP (Table 3). Lutein and $\beta$-carotene content of the lettuces from the GHP supply chain decreased significantly $(P<0.05)$ at the end of the trial (Table 3). However, compared to values at harvest their content did not show any significant change in lettuces from PHP supply chain. This indicates that the conditions prevailing in PHP supply chain did not show any adverse effect in lutein and $\beta$-carotene retention. These results are in confirmation with the findings of Bergquist et al. (2005) who reported that carotenoids retained better in baby spinach when stored at $10^{\circ} \mathrm{C}$ than $2^{\circ} \mathrm{C}$. Similarly, the lutein and $\beta$-carotene contents of mangos (Vazquez-Salinas and Lakshminarayana, 2018), baby-leaf lettuce and salad rocket (Saini et al., 2016) were also found to be better retained when stored at higher temperatures. A significant increase was observed in the riboflavin content of lettuces from both GHP and PHP supply chains. The increase in riboflavin content of lettuces from the PHP supply chain was more marked and 2 folds higher than the values at harvest (Table 3). The literature concerning the effect of postharvest storage on the riboflavin content of fruit and vegetables is rather scarce. Watada (1987) reported that the riboflavin content of potatoes increased during postharvest storage while that of green beans decreased. Riboflavin is known to play an important role in the plant defense system against various biotic and abiotic stress factors (Dong and Beer, 2000). Therefore, the marked increase in the riboflavin content might be due to induction of the riboflavin synthesis as a response to stress factors prevailing in the PHP supply chains such as high temperature, microbial growth, and excessive transpiration.

Table 3 Carotenoids, vitamin, soluble sugar and organic acid content and microbial load of lettuces at harvest and at the end of retail display which were supplied through poor (PHP) and good handling practices (GHP).

\begin{tabular}{lccc}
\hline & At harvest & After 2 days at retail display \\
\hline & & PHP & GHP \\
Lutein $(\mathrm{ug} / 100 \mathrm{~g})$ & $1166.2 \pm 133.8 \mathrm{a}$ & $1161.7 \pm 16.8 \mathrm{a}$ & $896.0 \pm 27.2 \mathrm{~b}$ \\
$\beta$-carotene $(\mu \mathrm{g} / 100 \mathrm{~g})$ & $1728.5 \pm 158.5 \mathrm{a}$ & $1726.5 \pm 26.3 \mathrm{a}$ & $1567.0 \pm 66.2 \mathrm{~b}$ \\
Riboflavin $(\mu \mathrm{g} / 100 \mathrm{~g})$ & $71.8 \pm 13.7 \mathrm{a}$ & $158.0 \pm 3.8 \mathrm{~b}$ & $115.3 \pm 4.3 \mathrm{c}$ \\
Ascorbic $\mathrm{acid}(\mathrm{mg} / 100 \mathrm{~g})$ & $8.2 \pm 1.3 \mathrm{a}$ & $7.6 \pm 0.2 \mathrm{a}$ & $7.8 \pm 0.1 \mathrm{a}$ \\
Fructose $(\mathrm{g} / 100 \mathrm{~g})$ & $0.65 \pm 0.17 \mathrm{a}$ & $0.58 \pm 0.03 \mathrm{a}$ & $0.66 \pm 0.09 \mathrm{a}$ \\
Glucose $(\mathrm{g} / 100 \mathrm{~g})$ & $0.49 \pm 0.18 \mathrm{a}$ & $0.46 \pm 0.05 \mathrm{a}$ & $0.54 \pm 0.11 \mathrm{a}$ \\
Malic acid $(\mathrm{g} / 100 \mathrm{~g})$ & $0.42 \pm 0.02 \mathrm{a}$ & $0.60 \pm 0.22 \mathrm{~b}$ & $0.32 \pm 0.10 \mathrm{a}$ \\
Citric acid $(\mathrm{g} / 100 \mathrm{~g})$ & $0.06 \pm 0.01 \mathrm{a}$ & $0.21 \pm 0.09 \mathrm{~b}$ & $0.06 \pm 0.02 \mathrm{a}$ \\
\hline
\end{tabular}


The fructose, glucose, malic and citric acid contents of lettuces from the GHP supply chain did not exhibit any significant $(P>0.05)$ change at the end of 2 days of retail display in comparison with the values measured at harvest (Table 3). However, the malic and citric acid content of lettuces from the PHP supply chain increased significantly $(P<0.05)$ during the same period. Since malic and citric acid are the intermediates of the Krebs Cycle, the increased levels of these organic acids might indicate an increase in the respiration rate of lettuces due to high temperatures observed in the PHP supply chain study.

\section{Tomato supply chain}

Weight loss and saleability

The time-temperature record of the tomato supply chains was given in Figure 3. The averages of the temperatures recorded all through the supply chain were $14.3^{\circ} \mathrm{C}$ and $28.6^{\circ} \mathrm{C}$ for GHP and PHP supply chain studies, respectively.

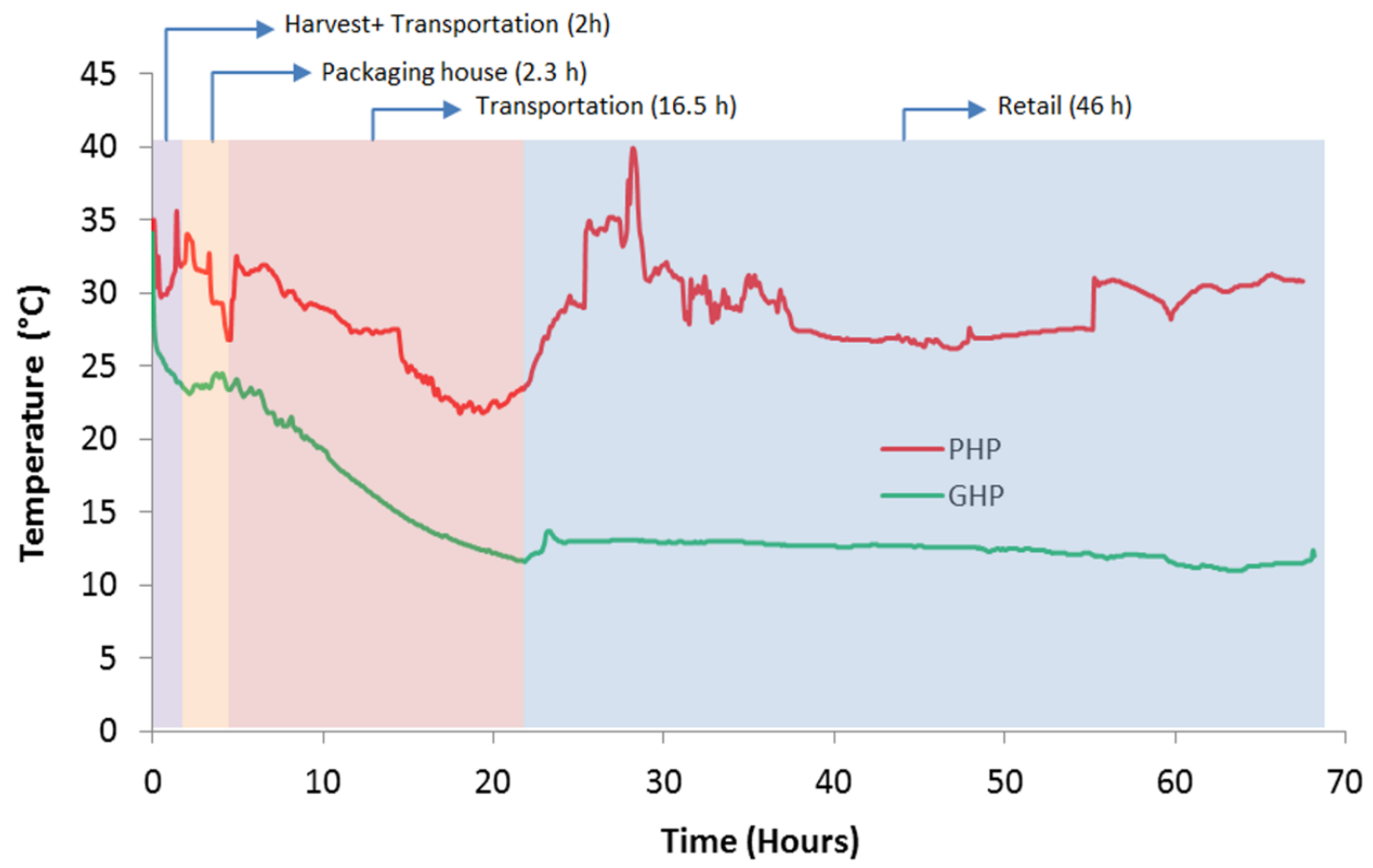

Figure 3 The time-temperature histories of the tomato supply chain with good (GHP) and poor postharvest handling practices (PHP).

Compared to lettuce, tomato is more resistant to water loss due its surface area is narrow and cuticle layer which limits transpiration. As can be seen from Table 1, at the end of two days of retail display tomatoes from PHP supply chain lost $4.5 \%$ of their initial weight compared to $0.5 \%$ of weight loss observed in tomatoes from GHP supply chain. The extent of weight loss in tomatoes was lower than in lettuce, however, the difference between the PHP and GHP supply chains was higher (9-fold) than the lettuce trial. When the whole supply chain was evaluated, the major stages at which the weight loss was higher were transportation $(3.2 \%)$ and retail display $(0.8 \%)$. As it was also observed in the lettuce study, the weight loss occurred during the supply chain does not reflect truly the real commercial loss, because, when tomatoes were assessed visually for their saleability, the tomatoes from the PHP supply chain were totally unsaleable due to spoilage (Table 1). However, tomatoes of the GHP supply chain were still saleable as no visual defects were observed which could hamper the purchasing decision of the consumers. 
Table 4 Microbial load of tomatoes at harvest and at the end of retail display which were supplied through poor (PHP) and good handling practices (GHP).

\begin{tabular}{lccc}
\hline & At harvest & After 2 days at retail display \\
\hline & & PHP & GHP \\
Coliform $(\log C F U / g)$ & $<1$ & $2.97 \pm 0.15$ & $<1$ \\
Mold $(\log C F U / g)$ & $2.53 \pm 0.15 \mathrm{a}$ & $2.58 \pm 0.11 \mathrm{a}$ & $<1$ \\
\hline
\end{tabular}

\section{Changes in microbial quality}

The microbiological quality of the tomatoes was assessed on the basis of mold and coliform count. As can be seen from Table 4, $2.53 \pm 0.15$ $\log \mathrm{CFU} / \mathrm{g}$ of mold was detected in tomatoes sampled immediately after harvest. In tomatoes that were subjected to PHP thorough out the supply chain, mold content increased up to 2.58 $\pm 0.11 \log \mathrm{CFU} / \mathrm{g}$ which was not significantly different from the initial value. However, in tomatoes from GHP, no mold was detected at the end of the supply chain. Initially, no coliform bacteria were detected in tomatoes. However, at the end of the supply chain tomatoes subjected to PHP were found to contain $2.97 \pm 0.15$ $\log \mathrm{CFU} / \mathrm{g}$ of coliform bacteria whereas no coliform bacteria was detected in tomatoes from the GHP supply chain indicating the beneficial effect of GHP on the tomatoes' microbial quality.

Table 5 Carotenoids, vitamin, soluble sugar and organic acid content of tomatoes at harvest and at the end of retail display which were supplied through poor (PHP) and good handling practices (GHP).

\begin{tabular}{lccc}
\hline & At harvest & \multicolumn{2}{c}{ After 2 days at retail display } \\
\hline & & PHP & GHP \\
Lycopene $(\mu \mathrm{g} / 100 \mathrm{~g})$ & $6119.8 \pm 146.5 \mathrm{a}$ & $6150.3 \pm 38.3 \mathrm{a}$ & $6016.8 \pm 49.3 \mathrm{~b}$ \\
$\beta$-carotene $(\mu \mathrm{g} / 100 \mathrm{~g})$ & $528.4 \pm 14.0 \mathrm{a}$ & $487.6 \pm 4.3 \mathrm{~b}$ & $495.8 \pm 3.8 \mathrm{~b}$ \\
Ascorbic acid $(\mathrm{mg} / 100 \mathrm{~g})$ & $19.7 \pm 0.8 \mathrm{a}$ & $15.5 \pm 0.1 \mathrm{~b}$ & $16.8 \pm 0.2 \mathrm{c}$ \\
Fructose $(\mathrm{g} / 100 \mathrm{~g})$ & $1.45 \pm 0.11 \mathrm{a}$ & $1.38 \pm 0.03 \mathrm{a}$ & $1.35 \pm 0.06 \mathrm{a}$ \\
Glucose $(\mathrm{g} / 100 \mathrm{~g})$ & $1.19 \pm 0.04 \mathrm{a}$ & $1.32 \pm 0.01 \mathrm{~b}$ & $1.30 \pm 0.03 \mathrm{~b}$ \\
Malic acid $(\mathrm{g} / \mathrm{kg})$ & $0.49 \pm 0.05 \mathrm{a}$ & $0.44 \pm 0.06 \mathrm{a}$ & $0.54 \pm 0.01 \mathrm{~b}$ \\
Citric acid $(\mathrm{g} / \mathrm{kg})$ & $5.79 \pm 0.36 \mathrm{a}$ & $6.22 \pm 0.27 \mathrm{~b}$ & $5.36 \pm 0.33 \mathrm{a}$ \\
\hline
\end{tabular}

\section{Changes in nutritional quality}

The change in the nutritional quality of tomatoes was assessed on the basis of major carotenoids, lycopene and $\beta$-carotene, and ascorbic acid content (Table 5). Among different nutritive compounds, lycopene was the most abundant and tomatoes were found to contain $6119.8 \pm 146.5$ $\mu \mathrm{g} / 100 \mathrm{~g}$ of lycopene at harvest. The lycopene content of tomatoes at the end of the supply chain from PHP and GHP supply chain trials was not significantly $(p>0.05)$ different. However, $\beta$ carotene content of the tomatoes from both supply chains studies was significantly $(\mathrm{p}<0.05)$ lower than the values measured at harvest, but these values were not significantly $(p>0.05)$ different from each other. In tomatoes, carotenoids are synthesized through the carotenoid biosynthesis pathway where lycopene serves as a precursor for the synthesis of $\beta$ - carotene (Marty et al., 2005). In general, tomato carotenoid content was reported to increase with ripening (Davies et al., 1981). Due to high temperatures attained during PHP supply chain (Figure 3) tomatoes seems to ripen/senescence faster than those from GHP. As a result, slightly higher lycopene and $\beta$-carotene contents were observed in tomatoes from PHP than GHP supply chain. The ascorbic acid content of tomatoes was reported to decrease with ripening (Oms-Oliu et al., 2011) and during high temperature storage (Lee and Kader, 2000) confirming our observation that the tomatoes from PHP lost significantly $(\mathrm{p}<0.05)$ more ascorbic acid than those from GHP.

The glucose and fructose were the major sugars found in tomatoes (Davies et al., 1981). Sucrose was not detected in any of the samples studied. 
Regardless of the supply chain conditions, compared to their initial values at harvest, glucose content of tomatoes significantly $(P<0.05)$ increased whereas fructose content did not show any significant $(P>0.05)$ change at the end of the supply chain trial (Table 5). Regarding organic acids, the citric acid content of the tomatoes from PHP increased significantly $(P<0.05)$ whereas malic acid content did not exhibit any significant $(P>0.05)$ change compared to values measured at harvest (Table 5). An opposite pattern of change was observed for the tomatoes from GHP supply chain. These results were in accordance with the findings of Oms-Oliu et al. (2011) who reported that as fruit begin to ripen, the increased catabolic activity of the malic enzyme and the continued activity of malate dehydrogenase and citrate synthase leads to a decline in malic levels and the preferential accumulation of citric acid in tomatoes.

\section{CONCLUSION}

It can be concluded that, still huge amounts of postharvest losses can be avoided if good postharvest handling practices are employed with a holistic perspective in fresh produce supply chains. The supply chain steps at which prolonged exposure to high temperatures occurred, namely, retail display and transportation, were the most critical stages where improvement efforts should be focused. The results of this study also showed that the quantification of commercial loss solely on the basis of weight loss can be misleading as it does not necessarily reflect the saleability of the produces. In prospect, it would be of interest to enlarge the methodology used in this study to other fruits and vegetables in order to have a much wider and complete understanding of the reasons and amounts of the losses occurring in the fresh produce supply chains.

\section{CONFLICT OF INTEREST}

The authors declare no conflict of interest.

\section{AUTHOR CONTRIBUTIONS}

İbrahim Sani Özdemir designed and directed the project, performed experiments, wrote the article Hatice Semizer Aksoy performed experiments, contributed to the article writing.

\section{ACKNOWLEDGMENTS}

This work was financially supported by Metro Gross Market Bakırköy Alışveriş Hizmetleri Tic. Ltd. Şti. under TUBITAK MRC project (Project No: 5164107). Authors also would like to thank Tülay ÖZEL and Özgür AYDINLI for their support in field studies.

\section{REFERENCES}

Agüero, M.V., Ponce, A.G., Moreira, M.R., Roura, S.I. (2011). Lettuce quality loss under conditions that favor the wilting phenomenon. Postharvest Biol Technol, 59: 124-131, https://doi.org/https://doi.org/10.1016/j.posth arvbio.2010.08.018

Bergquist, S.Å.M., Gertsson, U.E., Olsson, M.E. (2005). Influence of growth stage and postharvest storage on ascorbic acid and carotenoid content and visual quality of baby spinach (Spinacia oleracea L.). J Sci Food Agric, 86:346-355, https://doi.org/10.1002/jsfa.2373

Davies, J.N., Hobson, G.E., McGlasson, W.B. (1981). The constituents of tomato fruit - the influence of environment, nutrition, and genotype. C R C Crit Rev Food Sci Nutr, 15: 205280 , 10408398109527317

Dong, H., Beer, S.V. (2000). Riboflavin induces disease resistance in plants by activating a novel signal transduction pathway. Phytopathology, 90: 801-811.

Falomir, M.P., Gozalbo, D., Rico, H. (2010). Coliform bacteria in fresh vegetables: from cultivated lands to consumers. Curr Res Technol Educ Top Appl Microbiol Microb Biotechnol, 2:11751181.

Geysen, S., Escalona, V.H., Verlinden, B.E., Aertsen, A., Geeraerd, A.H., Michiels, C.W., Van Impe, J.F., Nicolaï, B.M.(2006). Validation of predictive growth models describing superatmospheric oxygen effects on Pseudomonas fluorescens and Listeria innocua on fresh-cut lettuce. Int J Food Microbiol, 111: 4858, https://doi.org/10.1016/j.ijfoodmicro. 2006.04.044 
Gogo, E.O., Opiyo, A.M., Ulrichs, C., HuyskensKeil, S. (2017). Nutritional and economic postharvest loss analysis of African indigenous leafy vegetables along the supply chain in Kenya. Postharvest Biol Technol,130:39-47, https://doi.org/10.1016/j.postharvbio.2017.04.0 07

Hodges, R.J., Buzby, J.C., Bennett, B. (2011). Postharvest losses and waste in developed and less developed countries: opportunities to improve resource use. J Agric Sci, 149:37-45, https://doi.org/DOI:

\subsection{7/S0021859610000936}

Kader, A.A.(2005). Increasing food availability by reducing postharvest losses of fresh produce. Acta Hort, 2169-2176, https://doi.org/10.17660/ ActaHortic.2005.682.296

Kelly, K., Madden, R., Emond, J.P., do Nascimento Nunes, M.C.(2019). A novel approach to determine the impact level of each step along the supply chain on strawberry quality. Postharvest Biol Technol, 147:78-88, https://doi.org/10.1016/j.postharvbio.2018.09.0 12

Kim, M.J., Moon, Y., Tou, J.C., Mou, B., Waterland, N.L.(2016). Nutritional value, bioactive compounds and health benefits of lettuce (Lactuca sativa L.). J Food Compos Anal, 49:19-34, 10.1016/j.jfca.2016.03.004 https://doi.org/

Lebersorger, S., Schneider, F.(2014). Food loss rates at the food retail, influencing factors and reasons as a basis for waste prevention measures. Waste Manag, 34:1911-1919, https://doi.org/ 10.1016/j.wasman.2014.06.013

Lee, S.K, Kader, A.A.(2000). Preharvest and postharvest factors influencing vitamin $C$ content of horticultural crops. Postharvest Biol Technol, 20:207-220, https://doi.org/10.1016/S09255214(00)00133-2

Managa, M.G., Tinyani, P.P., Senyolo, G.M., Soundy, P., Sultanbawa, Y., Sivakumar, D.(2018). Impact of transportation, storage, and retail shelf conditions on lettuce quality and phytonutrients losses in the supply chain. Food Sci Nutr, 6:15271536, https://doi.org/10.1002/fsn3.685
Marsh, K.S., Hammig, M.D., Singer, N.S.(2001). Estimates of international transport losses of world food supply. J Int Food Agribus Mark, 12:69_ 84, https://doi.org/10.1300/J047v12n03_04

Marty, I., Bureau, S., Sarkissian, G., Gouble, B., Audergon, J.M., Albagnac, G.(2005). Ethylene regulation of carotenoid accumulation and carotenogenic gene expression in colourcontrasted apricot varieties (Prunus armeniaca). J Exp Bot, 56:1877-1886, https://doi.org/ $10.1093 / \mathrm{jxb} / \mathrm{eri1} 77$

Mena, C., Terry, L.A., Williams, A., Ellram, L.(2014). Causes of waste across multi-tier supply networks: Cases in the UK food sector. Int J Prod Econ, 152:144-158, https://doi.org/10.1016/ j.ijpe.2014.03.012

Nunes, M.C.N., Emond, J.P., Dea, S., Yagiz, Y.(2011). Distribution center and retail conditions affect the sensory and compositional quality of bulk and packaged slicing cucumbers. Postharvest Biol Technol, 59:280-288, https://doi.org/10.1016/j.postharvbio.2010.10.0 04

Nunes, M.C.N., Emond, J.P., Rauth, M., Dea, S., Chau, K.V. (2009). Environmental conditions encountered during typical consumer retail display affect fruit and vegetable quality and waste. Postharvest Biol Technol, 51:232-24, https://doi.org/10.1016/j.postharvbio.2008.07.0 16

Oms-Oliu, G., Hertog, M.L.A.T.M., Van de Poel, B., Ampofo-Asiama, J., Geeraerd, A.H., Nicolaï, B.M.(2011). Metabolic characterization of tomato fruit during preharvest development, ripening, and postharvest shelf-life. Postharvest Biol Technol, 62:7-16, https://doi.org/ 10.1016/j.postharvbio. 2011.04.010

Paull, R.(1999). Effect of temperature and relative humidity on fresh commodity quality. Postharvest Biol Technol, 15:263-277, https://doi.org/10.1016/S0925-5214(98)000908

Rediers, H., Claes, M., Peeters, L., Willems, K.A.(2009). Evaluation of the cold chain of freshcut endive from farmer to plate. Postharvest Biol 
Technol, 51:257-262, https://doi.org/10.1016/ j.postharvbio.2008.07.017

Saini, R.K., Shang, X.M., Ko, E.Y., Choi, J.H., Keum, Y.S.(2016). Stability of carotenoids and tocopherols in ready-to-eat baby-leaf lettuce and salad rocket during low-temperature storage. Int J Food Sci Nutr, 67:489-495, https://doi.org/ 10.3109/09637486.2016.1172059

Saltveit, M.E.(2003). Temperature extremes. In: Postharvest Physiology and Pathology of Vegetables, Bartz, J.A., Brecht, J.K. (Eds.), Marcel Dekker, New York, pp. 457-483.

Turkstat (2018). Population statistics by provinces [https://data.tuik.gov.tr/Kategori/ GetKategori? $p=$ nufus-ve-demografi-109\&dil=1].

Vazquez-Salinas, C., Lakshminarayana, S.(2018). Compositional Changes in Mango Fruit During
Ripening at Different Storage Temperatures. J Food Sci, 50:1646-1648, https://doi.org/10.1111/ j.1365-2621.1985.tb10555.x

Watada, A.E.(1987). Vitamins C, B1, and B2 contents of stored fruits and vegetables as determined by high performance liquid chromatography. J Am Soc Hortic Sci, 112:794797.

Wiley, R.C.(1994). Preservation methods for minimally processed refrigerated fruits and vegetables. In: Minimally Processed Refrigerated Fruits \& Vegetables, Wiley, R.C. (Ed.), Springer, Boston, MA, pp. 66-134. 